\title{
Protection or cytotoxicity mediated by a novel quinonoid-polyphenol compound?
}

\author{
Ivana Milackova, Lucia Rackova, Magdalena Majekova, Natasa Mrvova and Milan Stefek \\ Institute of Experimental Pharmacology and Toxicology, Slovak Academy of Sciences, Dubravska cesta 9, 84104 Bratislava, \\ Slovak Republic
}

\begin{abstract}
Many natural and synthetic quinones and naphthoquinones possess a variety of beneficial pharmacological properties. In plants, the cytotoxic properties of quinones serve in their defensive roles against invading bacteria, fungi and parasites. In this regard many quinones as well as polyphenols, exerting generally toxicity at high dosages, are able to induce favorable hormetic responses at a low dosage. The novel chloronaphthoquinone derivative of quercetin (CHNQ) showed a profound cytotoxicity followed by enhancement of intracellular generation of oxidants in human neonatal BHNF-3 fibroblasts. Its synthetic precursors, quercetin and 2-chloro-3-hydroxy-[1,4]naphthoquinone, failed to induce these effects, and paradoxically, only CHNQ at a low concetration provided partial protection of the cells against oxidative challenge. Thus, the novel quinonoid-polyphenol CHNQ might have a merit in the search for new prospective agents in prevention and management of ageing and ageing-related pathologies.
\end{abstract}

Key words: Hormesis - Quinones - CHNQ - Oxidative stress

\section{Introduction}

Several of the most widely distributed quinones and naphthoquinones are reported to possess a variety of pharmacological properties, including anti-inflammatory, antifertility, leishmanicidal, antibacterial, antifungal, hypolipidemic, antiatherosclerotic, and antimalarial effects (Thomson 1971; Qiu et al. 1998; Kayembe et al. 2010; Tandon and Kumar 2013; Xu et al. 2014).

Some quinones have important roles in the biochemistry of energy production and serve vital links in electron transport. Defensive features have been attributed to other quinones with regard to their effectiveness in inhibiting the growth of bacteria, fungi or parasites. Possible mechanisms mediating the biological activity of quinones and naphthoquinones encompass modifications of target proteins by their keto-moieties linking to thiol- and amino-groups of protein amino acid residues (Bolton et al. 1997; Li et al. 2005). Furthermore, quinones can produce oxidative stress

Correspondence to: Lucia Rackova, Institute of Experimental Pharmacology and Toxicology, Slovak Academy of Sciences; Dubravska cesta 9, 84104 Bratislava, Slovak Republic

E-mail: lucia_rackova@hotmail.com by quinone redox cycling, involving enzymatic reduction to semiquinone radicals followed by oxidation by molecular oxygen and superoxide generation. In case of quinone electron carriers, this can result in inhibition of the cell respiratory chain by interference with the cell electron transport system (O'Brien 1991).

Recently a novel chloronaphthoquinone derivative of quercetin 3,7-dihydroxy-2-[4-(2-chloro-1,4-naphtoquinone-3-yloxy)-3-hydroxyphenyl]-5-hydroxychromen-4one, shortly chloronaphthoquinone quercetin or CHNQ (Fig. 1) was synthesized and studied (Stefek et al. 2012; Veverka et al. 2013; Milackova et al. 2013). The compound CHNQ showed profound antioxidant properties in a chemical model of DPPH test with an efficacy similar to the reference antioxidant trolox (Milackova et al. 2013).

Hormetic paradigm has been frequently linked to the famous statement of the German philosopher Friedrich Nietzsche (1844-1900): „What doesn't kill us makes us stronger" (Was uns nicht umbringt macht uns stärker). In the fields of biology and medicine, the term hormesis describes a biphasic dose-response with a low dose stimulation or beneficial effect and a high dose inhibitory or toxic effect. The response of the cell or organism to the low sub-lethal dose of the toxin is considered an adaptative compensatory process 
a<smiles>O=c1c(O)c(-c2ccc(O)c(O)c2)oc2cc(O)cc(O)c12</smiles>

b<smiles>O=C1C(O)=C(Cl)C(=O)c2ccccc21</smiles>

quercetin and 2-chloro-3-hydroxy-[1,4]naphthoquinone, shortly "quinone“, in human neonatal B-HNF-3 fibroblasts with aid of a molecular modeling method. In addition, we studied the cytotoxic effects of CHNQ as well as its potential paradoxic protection at low dose in oxidative stress challenged B-HNF-3 cells.

\section{Materials and Methods}

\section{Chemicals}

The compound CHNQ (purity > 99.5\%) was synthesized, purified and verified by BEL/NOVAMANN (Bratislava, Slovakia) as was described before (Veverka et al. 2013). CHNQ was prepared by sequential procedure involving selective protection of quercetin - $\mathrm{OH}$ groups followed by acylation with 2,3-dichloro-1,4-naphthoquinone. 2chloro-3-hydroxy-[1,4]naphthoquinone (quinone) was obtained from Bare Chemicals GmbH (Germany), quercetin from BEL/NOVAMANN (Slovakia), dimethylsulphoxide (DMSO) molecular biology grade was obtained from AppliChem, Minimum Essential Medium Eagle (MEM) from Sigma-Aldrich (Germany), fetal bovine serum (FBS) was obtained from PAA Laboratories (Austria). Penicillin, streptomycin and Dulbecco's phosphate buffer saline (PBS) were from Lonza (Belgium). Acridine orange (AO), ethidium bromide (EB), 2',7' -dichlorodihydrofluorescein diacetate $\left(\mathrm{H}_{2} \mathrm{DCF}-\mathrm{DA}\right)$, dihydroethidium (DHE), 4',6-diamidino-2-phenylindole (DAPI), hydrogen peroxide, neutral red, 2,4-dinitrophenylhydrazine (DNPH), polyclonal antibody antidinitrophenyl from rabbit as well as other chemicals were purchased from Sigma-Aldrich (Germany). Tetramethyl rhodamine isothiocyanate (TRITC)-labeled- polyclonal anti-rabbit antibody from goat was purchased from Dianova (Germany). Cell Proliferation Kit I ((3-[4,5-dimethyldiazol-2yl]-2,5-diphenyl-tetrazolium bromide)-MTT) was from Roche Diagnostics (Germany). JC-1 was from Santa Cruz (Heidelberg, Germany) and Caspase-Glo 8 Assay kit was from Promega (Mannheim, Germany).

\section{Cell culture}

B-HNF-3 (human neonatal fibroblasts) were obtained from Dr. Luboš Danišovič (Institute of Medical Biology, Genetics and Clinical Genetics, Faculty of Medicine, Comenius University in Bratislava, Slovakia) (Repiska et al. 2010). Cells were grown at $37^{\circ} \mathrm{C}$ in humidified air with $5 \% \mathrm{CO}_{2}$ in MEM supplemented with $10 \% \mathrm{FBS}, 100 \mathrm{IU} / \mathrm{ml}$ penicillin and $100 \mu \mathrm{g} / \mathrm{ml}$ streptomycin. Cells were subcultured once a week. The cells at up to 25 passages were used for experiments. 


\section{Molecular modeling}

The structures of the compounds tested (chlorohydroxynaphthoquinone, CHNQ and quercetin) were subjected to comparative molecular modeling. Low energy conformations (starting geometries) of the compounds studied were obtained by Monte Carlo equilibrium conformer search (MMFF94) and subsequent optimization in DFT B3LYP 6$31 \mathrm{G}^{\star}$ method, all performed in the program SPARTAN'08 (Wavefunction Inc., USA) (Shao et al. 2006). The values of orbital energies $\mathrm{E}_{\mathrm{HOMO}}$ (the highest occupied molecular orbital) and $\mathrm{E}_{\mathrm{LUMO}}$ (the lowest unoccupied molecular orbital) were obtained for final geometries optimized. To search for the most probable anionic form of quercetin and CHNQ, we performed calculations for all possible dissociated forms of both molecules and then anions with minimum energy (7- $\mathrm{O}^{-}$for both quercetin and $\mathrm{CHNQ}$, in vacuum and water) were chosen for further studies.

\section{Apoptosis/necrosis detection}

The apoptotic/necrotic changes were assessed by ethidium bromide and acridine orange (EB/AO) staining assay (Ribble et al. 2005; Rackova et al. 2009). After trypsinization, five thousand cells were grown in a 96-well plate in complete MEM for 24 hours. Subsequently, the cells were incubated with various concentrations of the compounds tested prepared from the stock solutions in DMSO (final concentration up to $0.33 \%)$. After 24 -h incubation the medium was changed and the cells were stained with $\mathrm{EB} / \mathrm{AO}$ (final concentrations $0.003 \mu \mathrm{M} / 0.005 \mu \mathrm{M}$, respectively) for $5 \mathrm{~min}$ in complete MEM and finally washed three times with PBS. The stained cells were examined using a fluorescence microscope Leica DM IL LED running standard software. Additionally, the effect of CHNQ on mitochondrial membrane potential (MMP) and caspase 8 activation were assessed. Following the treatment of B-HNF-3 cells (30 000 cells in $200 \mu \mathrm{l} /$ well) with the compounds tested in 96-well plates, the cultures were incubated with the freshly prepared JC-1 solution $(5 \mu \mathrm{g} / \mathrm{ml})$ in $5 \% \mathrm{CO}_{2}$ atmosphere at $37^{\circ} \mathrm{C}$ for $30 \mathrm{~min}$. After JC-1 was removed, the cells were washed trice with PBS and viewed under a fluorescence microscope Leica DM IL LED. Alternatively, the influence of MMP was evaluated by flow cytometric analysis. The cells grown in $6 \mathrm{~cm}$ Petri dishes were trypsinized, washed and stained by JC- 1 solution as described above. The labelled cells $\left(1 \times 10^{6}\right)$ were washed twice in PBS and analyzed by flow cytometry. For assessment of individual samples, a total of 7500-gated events were analyzed per sample by flow cytometer (Cytomics FC 500; Beckman Coulter). Frequency plots were obtained for FL-1 (green) and FL-2 (orange) to determine the percentage of the population stained green and orange. For detection of caspase 8 activation induced by CHNQ, luminiscence assay using Caspase-Glo 8 Assay kit was performed according to the manufacturer's protocol. Twenty thousand cells were used for each measurement.

\section{Detection of intracellular oxidative stress}

Generation of intracellular oxidants was assessed using $\mathrm{H}_{2}$ DCF-DA and DHE probes with differing specificity to ROS. In brief, following the treatment with the compounds tested, the cells were incubated with $\mathrm{H}_{2}$ DCF-DA $(10 \mu \mathrm{M})$ or DHE $(10 \mu \mathrm{M})$ for 45 and $35 \mathrm{~min}$, respectively, in complete MEM followed by stainning with DAPI ( $4.5 \mu \mathrm{M}$ in PBS). Finally, the cells were washed three times and examined using fluorescence microscopy.

\section{Immunocytochemical assay of protein carbonyls}

One hundred thousand cells were grown over 24 hours in poly-L-lysine-coated Petri dishes $(3 \mathrm{~cm})$. Following the $24-\mathrm{h}$ incubation with the compounds tested, the cells were fixed in $99.8 \%$ ethanol/ether $(1: 1, \mathrm{v} / \mathrm{v})$, at $-20^{\circ} \mathrm{C}$ for $10 \mathrm{~min}$. Next, the cells were incubated with DNPH $(0.3 \% \mathrm{w} / \mathrm{v}$ in ethanol acidified with $\mathrm{H}_{2} \mathrm{SO}_{4}(1.5 \%)$ ) overnight at $4^{\circ} \mathrm{C}$. On the next day, the DNPH solution was carefully washed out and the cells were incubated with blocking buffer (1\% FBS in PBS at $4^{\circ} \mathrm{C}$ ) for $30 \mathrm{~min}$ and subsequently permeabilized with Triton $\mathrm{X}-100\left(0.1 \%\right.$ in PBS) for $5 \mathrm{~min}$ at $4^{\circ} \mathrm{C}$ and finally washed trice with blocking buffer. Next, the DNPH-derivatized cells were incubated with primary antibody (polyclonal anti-DNP antibody from rabbit, 1:200, 1 hour at $4^{\circ} \mathrm{C}$ ) followed by incubation with secondary antibody (anti-rabbit, TRITC-labeled, 1:1000, 1 hour at $4^{\circ} \mathrm{C}$ ). The nuclei were stained with DAPI and the fluorescence was examined using fluorescence microscope Leica DM IL LED. The fluorescence intensities were calculated using Image J (version 1.46r, NIH, http://rsbweb.nih.gov/ij/). The average parameter value for each treatment was calculated from at least 3 randomly selected images (minimum 20 cells in total). The cells treated with $\mathrm{H}_{2} \mathrm{O}_{2}(1 \mathrm{mM}, 20 \mathrm{~min}$ in complete MEM) were used as positive control.

\section{MTT assay}

The effect of the compounds tested and $\mathrm{H}_{2} \mathrm{O}_{2}$ on the activity of mitochondrial dehydrogenases of B-HNF-3 cells was assessed as reduction of 3-[4,5-dimethyldiazol-2-yl]-2,5diphenyl-tetrazolium bromide (MTT) by the cells in accordance with the manufacturer's protocol. In brief, from 5000 to 15000 cells were grown in the 96-well plate for 24 hours. Then, following the next 24-hour incubation with the concentration range of the compounds tested or after additional 1-hour exposure to $\mathrm{H}_{2} \mathrm{O}_{2}$, the cells were incubated with MTT $(0.5 \mathrm{mg} / \mathrm{ml})$ for 4 hours in fresh MEM. The cells 
were exposed to $\mathrm{H}_{2} \mathrm{O}_{2}$ (0.5-5 mM in complete medium) following the 24-hour incubation with a low concentration $(10 \mu \mathrm{M})$ of the compounds tested.

\section{Neutral red assay}

Lysosomal stability following the oxidative insult was assessed as uptake of neutral red (NR) dye by acidic vacuoles of B-HNF-3 cells. One hundred microliters of NR solution $(0.003 \%)$ in complete MEM was added to the cells and the dye accumulation was left to proceed for 4 hours. Next, the incubation medium was removed, the cells were washed twice with PBS and the accumulated dye was solubilized with $2 \%$ acetic acid/ethanol mixture $(1: 1, \mathrm{v} / \mathrm{v})$. The absorbance of the samples was read spectrophotometrically at $540 \mathrm{~nm}$ using a reference wavelength at $690 \mathrm{~nm}$.

\section{Statistical analysis}

Data are presented as means \pm standard deviation (SD) of three separate experiments. Statistical analysis was performed using Student's $t$-test and statistical significance is expressed as ${ }^{\star} p<0.05 ;{ }^{* *} p<0.01 ;{ }^{* *} p<0.001 v s$. respective control. The $\mathrm{IC}_{50}$ and $\mathrm{IC}_{25}$ were extrapolated from the dose-response graph. The drug concentrations that reduced the viability of cells by $50 \%\left(\mathrm{IC}_{50}\right)$ and $25 \%\left(\mathrm{IC}_{25}\right)$ were determined by plotting data points over a concentration range and calculating values using regression analysis of GraphPad Prism 6 software.

\section{Results}

\section{Molecular modeling}

The values of the orbital energies $\mathrm{E}_{\mathrm{HOMO}}$ and $\mathrm{E}_{\mathrm{LUMO}}$ are summarized in Table 1. The value of $\mathrm{E}_{\mathrm{HOMO}}$ of the compounds studied (reflecting their one-electron ionization potential) decreased in the order: quercetin > CHNQ > quinone. In accordance with these data, quinone exerted approximately a 30-times lower antioxidant effectiveness

Table 1. The values of the orbital energies $\mathrm{E}_{\mathrm{HOMO}}$ and $\mathrm{E}_{\mathrm{LUMO}}$ obtained by DFT B3LYP 6-31G* method

\begin{tabular}{lcc}
\hline Compounds & $\mathrm{E}_{\mathrm{HOMO}}(\mathrm{kJ} / \mathrm{mol})$ & $\mathrm{E}_{\mathrm{LUMO}}(\mathrm{kJ} / \mathrm{mol})$ \\
\hline quercetin & -528.83 & -177.77 \\
quinone & -661.39 & -326.80 \\
CHNQ & -548.25 & -356.83 \\
\hline
\end{tabular}

$\mathrm{E}_{\mathrm{HOMO}}$, the highest occupied molecular orbital; $\mathrm{E}_{\mathrm{LUMO}}$, the lowest unoccupied molecular orbital; CHNQ, chlorohydroxynaphthoquinone. in a chemical model of the DPPH test than did quercetin and $\mathrm{CHNQ}$, as documented by the values of initial rate of absorbance decreases $(\Delta \mathrm{A} / 75 \mathrm{~s})$ of the reaction mixtures containing DPPH radical in the presence of CHNQ: 0.462 \pm 0.015 ; quercetin: $0.386 \pm 0.025$ and quinone: $0.012 \pm 0.006$ (Milackova et al. 2013). The intrinsic prooxidant potential (reflected by $\mathrm{E}_{\mathrm{LUMO}}$ energies) gave the order: $\mathrm{CHNQ}>$ quinone $>$ quercetin.

\section{Detection of intracellular oxidative stress}

After passing through the plasma membrane, $\mathrm{H}_{2}$ DCF-DA ( $2^{\prime}, 7^{\prime}$-dihydrodichlorofluorescein diacetate $)$ - a lipophilic and non-fluorescent compound, is de-esterified to a hydrophilic phenol $\mathrm{H}_{2} \mathrm{DCF}$ (dihydrodichlorofluorescein) that may be oxidized to fluorescent DCF $\left(2^{\prime}, 7^{\prime}\right.$-dichlorofluorescein) by a process usually considered to involve ROS. The cells treated with CHNQ at $35 \mu \mathrm{M}$ showed a notable increase of $\mathrm{H}_{2} \mathrm{DCF}$ oxidation (Fig. 2). In paradox, no DCF fluorescence was observed at the highest concentration tested. Increased cell membrane permeability preventing successful retention of the oxidized probe might probably have contributed to this outcome.

However, maximum production of superoxide was seen in the cells treated with $100 \mu \mathrm{M}$ CHNQ, as visualized by intracellular fluorescence derived from DHE oxidation (localized to nuclear compartment, Fig. 3I), specific for superoxide. The increase of membrane permeability (shown as enhanced DAPI staining) was also counteracting the development of ethidium-derived fluorescence (shown as reduced colocalization of both stains, Fig. 3K). Yet again, quercetin and quinone did not cause probe oxidation at any of the concentrations tested (Fig. 3A-F).

\section{Immunocytochemical assay of protein carbonyls}

A significant increase of protein carbonyl immunoreactivity was observed in the cells treated by $35 \mu \mathrm{M}$ and $100 \mu \mathrm{M}$ CHNQ (Fig. 4). Fluorescence was localized to the cytosolic region of the cells. This was comparable with protein oxidation in the cells treated by hydrogen peroxide. Correspondingly to the detected level of intracellular oxidants, quercetin and quinone did not boost protein oxidation in the concentration range applied and CHNQ did not show protein carbonylation at the minimum concentration tested.

\section{Cytotoxicity of quinone, quercetin and CHNQ}

No influence of MTT reduction, or rather its slight enhancement, was observed in B-HNF-3 cells applied with the compounds tested up to the concentration of $25 \mu \mathrm{mol} / \mathrm{l}$. Treatment with higher doses resulted in a decline of formazan production with a significant cytotoxic effect of CHNQ 
(at concentrations $35 \mu \mathrm{M}(p<0.05 v s$. control), $50 \mu \mathrm{M}$ ( $p<$ $0.001 v s$. control) and $100 \mu \mathrm{M}(p<0.001 v s$. control), Fig. 5). Thus, the highest cytotoxicity was determined for CHNQ $\left(\mathrm{IC}_{50}=45.6 \pm 2.2 \mu \mathrm{M}, \mathrm{IC}_{25}=31.5 \pm 1.2 \mu \mathrm{M}\right)$, while both its precursors tested showed negligible cytotoxic effects $\left(\mathrm{IC}_{50}>>\right.$ $100 \mu \mathrm{M}, \mathrm{IC}_{25}=89.3 \pm 24.0 \mu \mathrm{M}$ and $\mathrm{IC}_{25}=96.5 \pm 26.9 \mu \mathrm{M}$, for quercetin and quinone, respectively). Application of DMSO did not cause any significant influence of formazan generation by the cells.

$\mathrm{EB} / \mathrm{AO}$ labeling showed an increased number of the cells displaying bright green nuclei (corresponding to nuclear condensation) and red intact nuclei following treatment with CHNQ, indicative of death induction by apoptosis and necrosis, respectively (Renvoize et al. 1998; Ribble et al. 2005), with a prevalence of the former (Fig. 6G-I). The cells treated by $100 \mu \mathrm{M}$ CHNQ showed also mostly a green nuclear AO staining, however, with a lower intensity, probably due to the aforementioned diminished retention of the dye by the permeabilized dead cells. These changes were not seen following treatment with quercetin and quinone at either of the concentrations tested (Fig. 6A-F). In addition, CHNQ at 35 and $100 \mu \mathrm{M}$ caused significant changes in morphology seen as cell shrinkage, roundicity increase with loss of the typical elongated shape, significant decrease of mitotic cells and remarkable decrease of cell adherence. Induction of apoptosis in the cells treated with CHNQ $(35 \mu \mathrm{M})$ was confirmed by a significant depolarization of mitochondrial membrane as confirmed by JC-1 stainning combined with fluorescent
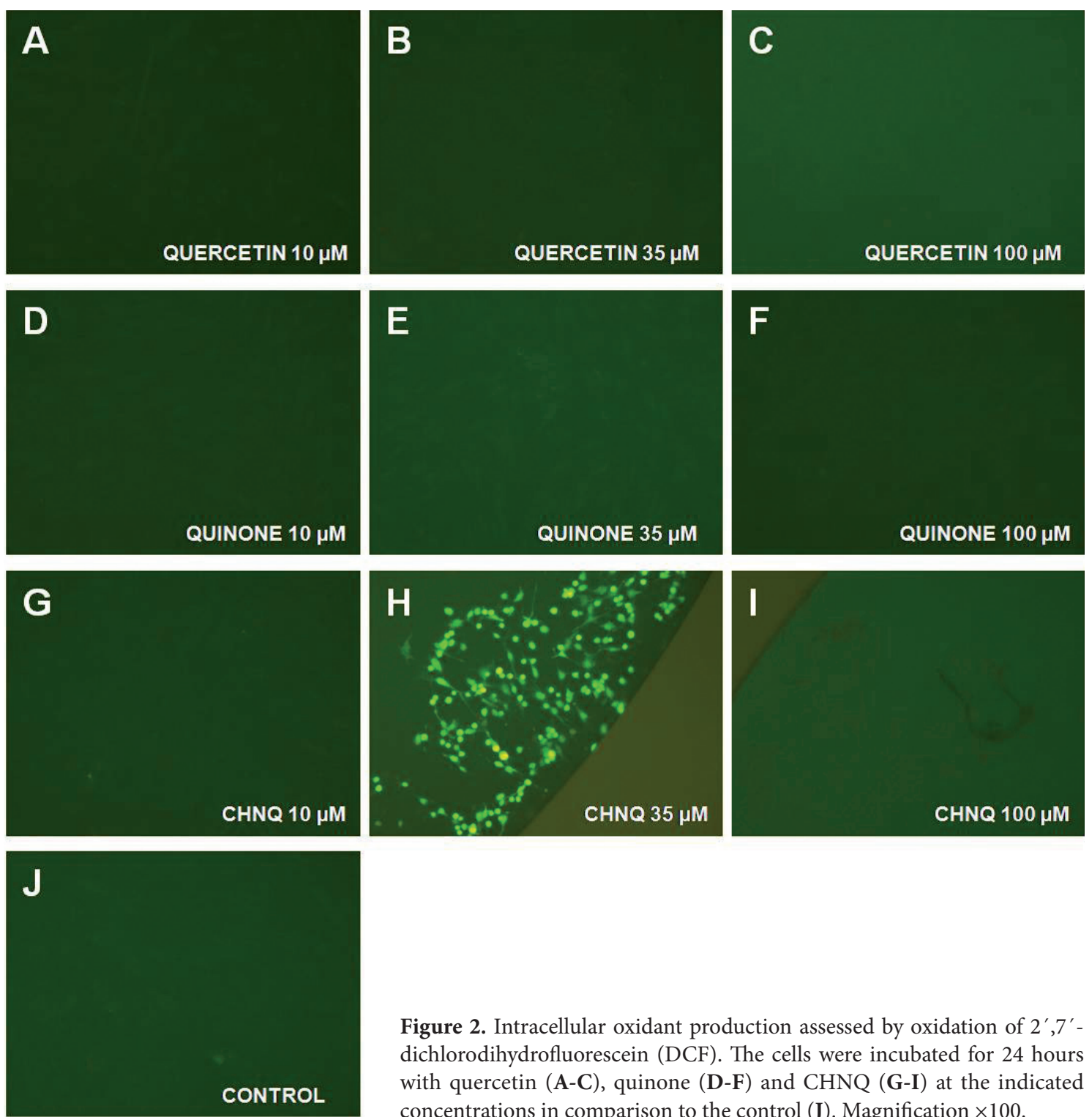

Figure 2. Intracellular oxidant production assessed by oxidation of $2^{\prime}, 7^{\prime}-$ dichlorodihydrofluorescein (DCF). The cells were incubated for 24 hours with quercetin (A-C), quinone (D-F) and CHNQ (G-I) at the indicated concentrations in comparison to the control $(\mathrm{J})$. Magnification $\times 100$. 
microscopy (depolarized mitochondria showed green fluorescence corresponding to JC-1 monomers, while polarized mitochondria displayed red fluoresence corresponding to aggregated dye) and flow cytometry (only $30.55 \pm 0.75 \%$ of the cell population treated with CHNQ displayed red fluorescence) (Fig. 7). Furthermore, a significant increase in caspase 8 activity was observed in the cells exposed to CHNQ $(35 \mu \mathrm{M}$, $174,863 \pm 34,515$ compared to $96,973 \pm 13,144$ R.L.U. (relative luminiscence units) of vehicle control, $p<0.05$ ).

In order to shed light on possible CHNQ decomposition and its role in the cytotoxicity profile, we compared the effect of CHNQ on MTT reduction with the effect of its equimolar precursor mixture. A remarkably lower activity of mitochondrial dehydrogenases was observed in the cells treated with the combination of individual precursors than in the cells applied with CHNQ (Fig. 8).

Protection by quinone, quercetin and CHNQ against $\mathrm{H}_{2} \mathrm{O}_{2}-$ induced injury

Treatment of the cells with $\mathrm{H}_{2} \mathrm{O}_{2}$ resulted in a concentrationdependent injury of metabolic activity (confirmed by MTT
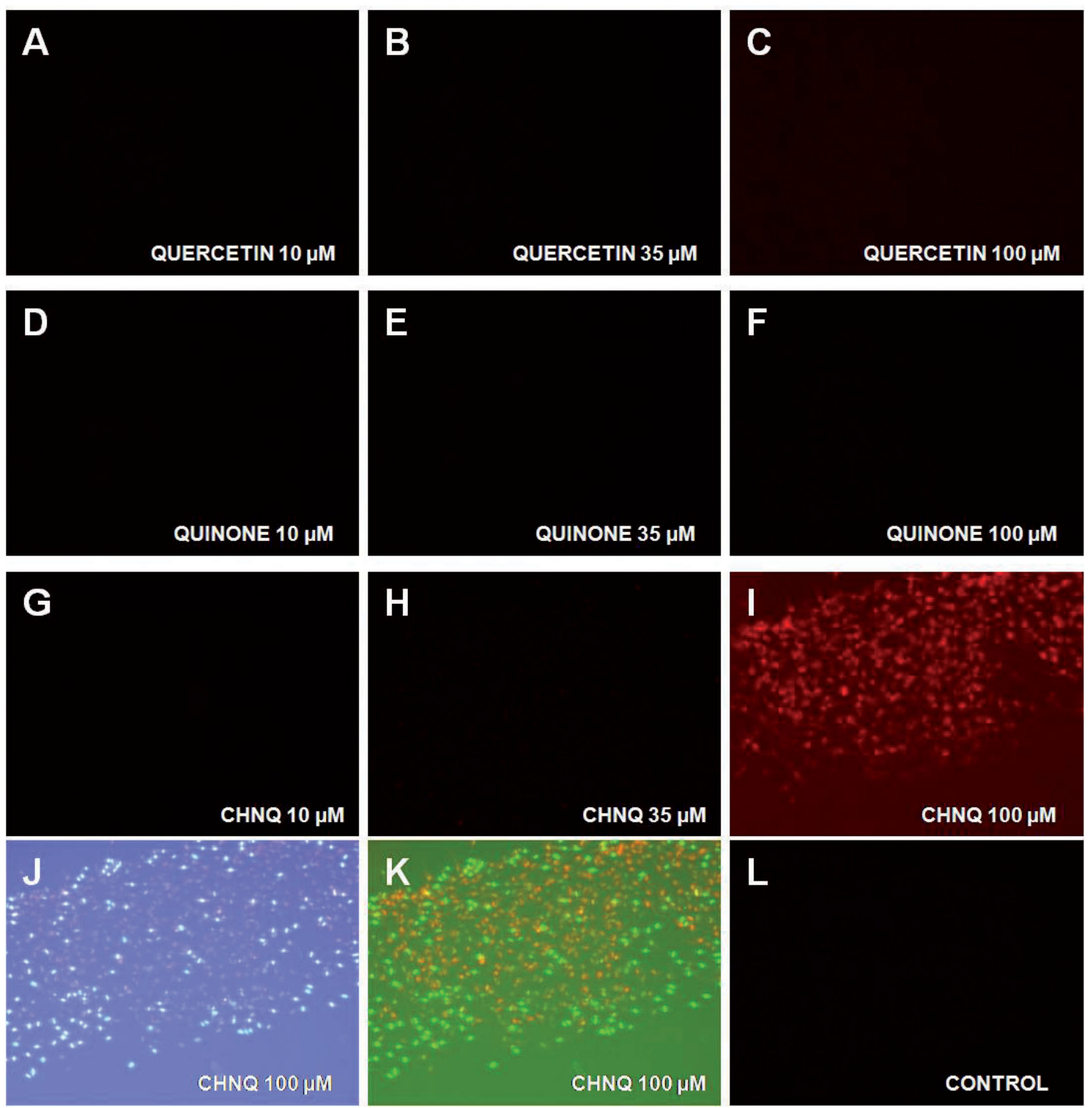

Figure 3. Intracellular oxidant production assessed by oxidation of dihydroethidium (DHE). The cells were incubated for 24 hours with quercetin (A-C), quinone (D-F) and CHNQ (G-I) at the indicated concentrations in comparison to the control (L). J. The nuclear staining of cells treated by $100 \mu \mathrm{M}$ CHNQ. K. Colocalisation of nuclear stainning (J) and oxidation-derived fluorescence (I). Magnification $\times 100$. 
conversion decline) as well as in lysosomal injury (proved by diminishment of neutral red uptake). A correlation was evident for the data collected from both assays, however, a higher vulnerability to $\mathrm{H}_{2} \mathrm{O}_{2}$ was seen in the lysosomal uptake-based assay (Fig. 9) (MTT test $\mathrm{LC}_{50}=2.99 \pm 0.71 ; \mathrm{NRU}$ assay $\mathrm{LC}_{50}=$ $1.79 \pm 0.55)$. Concentrations of $\mathrm{H}_{2} \mathrm{O}_{2}$ causing MTT reduction decline approximately by $50 \%$ were used for further assays.

In line with the proposition that electron-wihdrawing properties of a compound might trigger protection at low dose, twenty-four-hour pre-treatment with CHNQ (10 $\mu \mathrm{mol} / \mathrm{l})$ led to a mild prevention of decline of activity of mitochondrial dehydrogenases $\left(p<0.01\right.$ vs. $\mathrm{H}_{2} \mathrm{O}_{2}$ control $)$ and lysosomal injury ( $p<0.01 v s . \mathrm{H}_{2} \mathrm{O}_{2}$ control) caused by oxidative stress induced by $1 \mathrm{mM} \mathrm{H}_{2} \mathrm{O}_{2}$ (Fig. 9). However, neither of the non-toxic precursor substances did show a similar effect. Moreover, quercetin enhanced the lysosomal damage and quinone potentiated the mitochondrial dehydrogenases injury caused by hydrogen peroxide.

\section{Discussion}

Certain structural prerequisites have been proposed for the substances providing beneficial biological effects based on

\section{i) Immunofluorescence}
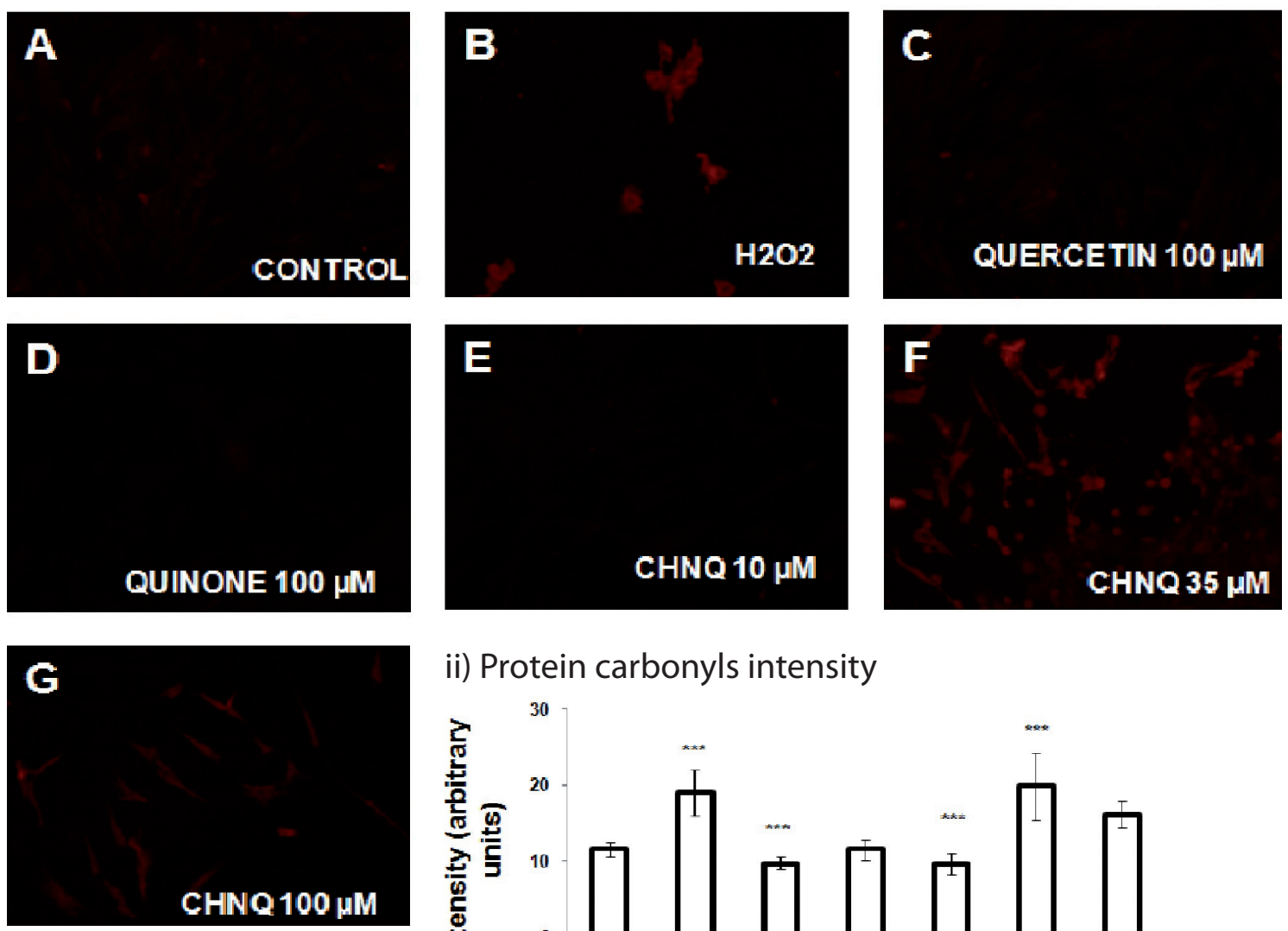

ii) Protein carbonyls intensity

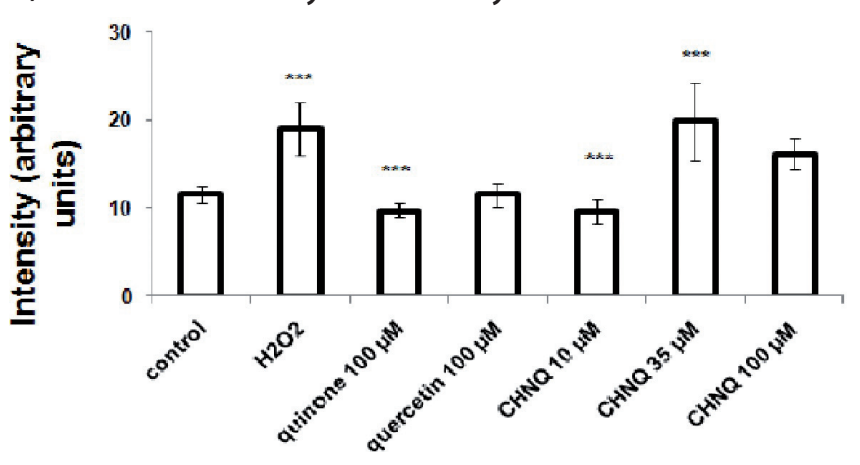

Figure 4. Protein oxidation in the cells following the exposure to the compounds CHNQ, quercetin and quinone in comparison to the control (i, $\mathbf{A})$ assessed by immunocytochemical labelling of protein carbonyls. The significant increase of protein carbonyls was comparable with protein oxidation in the cells treated by $1 \mathrm{mM} \mathrm{H}_{2} \mathrm{O}_{2}$ in complete medium for $20 \mathrm{~min}$ used as a positive control (i, B). The fluorescence intensities were quantified using Image J software (ii). The average parameter value for each treatment was calculated from at least 3 randomly selected images (minimum 20 cells in total). Magnification $100 \times$; ${ }^{* * *} p<$ 0.001 vs. control. 

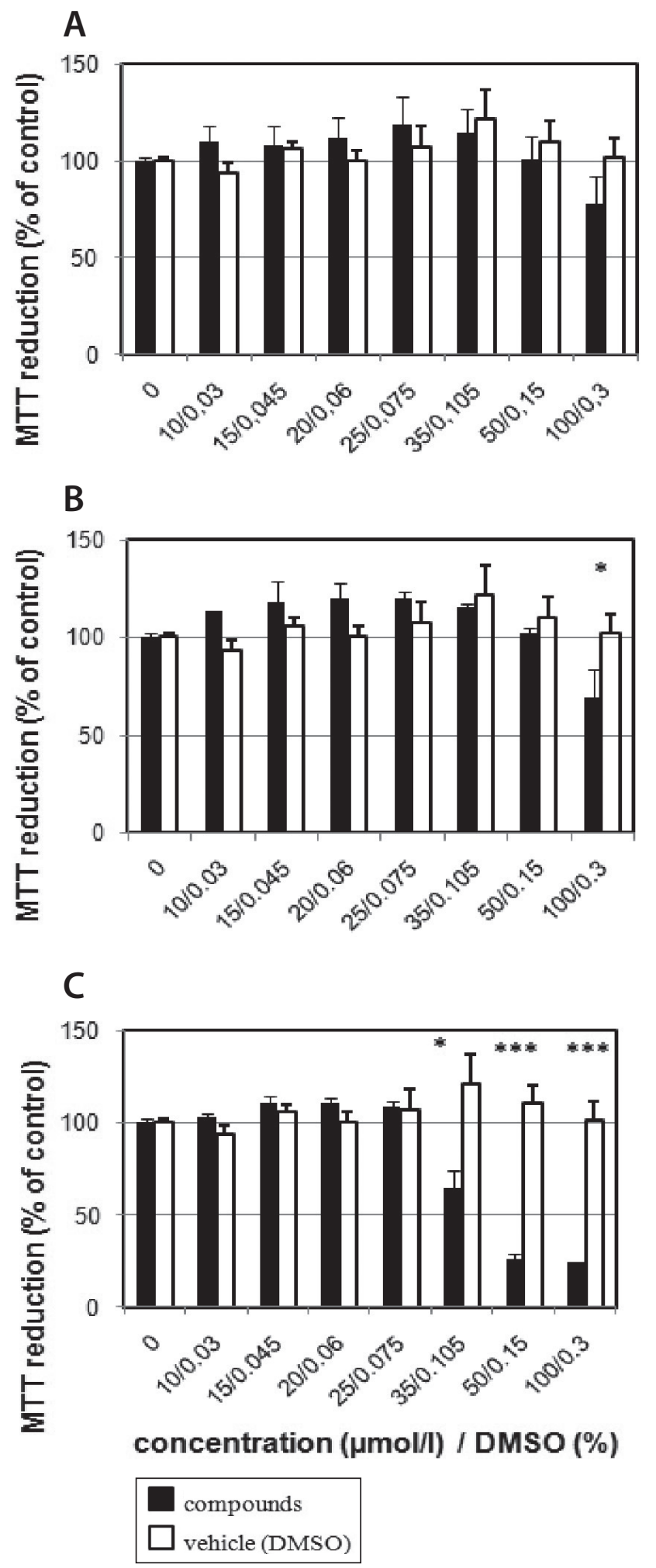

Figure 5. Comparison of viability (assessed by mitochondrial reduction of MTT) of B-HNF-3 cells after 24-hours treatment with CHNQ (C), its precursors quercetin (A) and quinone (B), and vehicle DMSO expressed as the percentage of control. ${ }^{\star} p<0.05$, ${ }^{* * *} p<0.001$ vs. control. oxidant-generation promoting mechanism. These involve electron-deficient moiety favoring electron transfer from the electron-rich biomolecules, such as protein cysteine residues or low-molecular weight thiols (Bergman et al. 1959). Depending on the redox properties and the applied dose range of a substance, this might result either in oxidative stress causing cell damage (a generally desired effect in case of treatment of malignancies or bacterial infection) or upregulation of the defense system, a phenomenon accompanying hormesis (Calabrese and Baldwin 1997). Hormesis, and particularly hormetic phytochemicals, represent a promising approach in management of ageing and ageing-related pathologies (Son et al. 2008). In all organisms, the cellular response to environmental stress includes transcriptional activation of enzymes that protect and repair cellular macromolecules (Gasch and WernerWashburne 2002; Kultz 2005). FOXO, cap-n-collar and other transcription factors have highly conserved roles in activating the expression of cytoprotective genes in response to oxidative, xenobiotic and thermal stress (Lee and Johnson 2004; Mathers et al. 2004; Kobayashi et al. 2006; Sedding 2008). These genes encode enzymes that scavenge free radicals, synthesize glutathione and catalyze conjugation reactions that increase xenobiotic solubility and excretion. A range of xenohormetic structures bear an electron accepting moiety, as e.g. $\alpha, \beta$-unsaturated carbonyl or isothiocyanate group, favoring covalent binding to nucleophilic residues of the regulators of critical transcription factors, such as reactive cysteine residues in redox-sensitive Nrf2/Keap 1 or HSF1-HSP90 heterocomplexes (Akhtar et al. 2012). This results in transcriptional activation and boosting of antioxidant defence, augmentation of detoxification processes or of the protein quality control system (Itoh et al. 1997; Itoh et al. 1999; DinkovaKostova et al. 2001). Naturally occurring quinones (such as juglone, vitamin $\mathrm{K}$, plumbagin) bearing $\alpha, \beta$-unsaturated carbonyl moieties represent typical xenohormetics (Shibayama-Imazu et al. 2006; Przybysz et al. 2009; Son et al. 2010). Furthermore, flavonoids might represent precursors of xenohormetic molecules and undergo conversion by oxidative metabolism which involves a two-electron auto-oxidation to an electrophilic quinone-type molecule (Metodiewa et al. 1999; Awad et al. 2000; Bast and Haenen 2002). In this regard, quercetin, as a precursor of ortho-quinone molecule, showed a range of beneficial effects on organisms including life extension of yeasts and nematodes, chemopreventive effects, enhancement of cognitive functions and protection of immune system in aged animals (Chondrogianni et al. 2010; Vargas and Burd 2010; Pietsch et al. 2011; Si and Liu 2014). However, since the lower bioavailabilty can counteract its beneficial effects, attempts to improve this characteristic through the structure modification have been reported (Murota 
and Terao 2003). Previous studies conducted by Chondrogianni et al. (2010) using quercetin caprylate showed that both quercetin and its novel derivative can induce rejuvenation of already senescent human fibroblasts. However, the senescence-reversing effects were not enhanced in the cells treated with novel compound compared to unsubstituted quercetin. Chemical synthesis (assisted by molecular modeling methods) may represent an efficient tool to optimize electron-acceptor properties of quinones, flavonoids and other prospective phytochemicals and thus improve their beneficial health potential.

In line with calculated molecular parameters of the compounds tested showing strongest electron-withdrawal potency, CHNQ induced a remarkable oxidant production by the cells as confirmed by specific oxidant-sensitive fluorogenic probes. Intracellular DHE oxidation confirmed generation of superoxide (as a primary reactive oxygen metabolite) in the cells treated with $\mathrm{CHNQ}$, which might occur via quinone
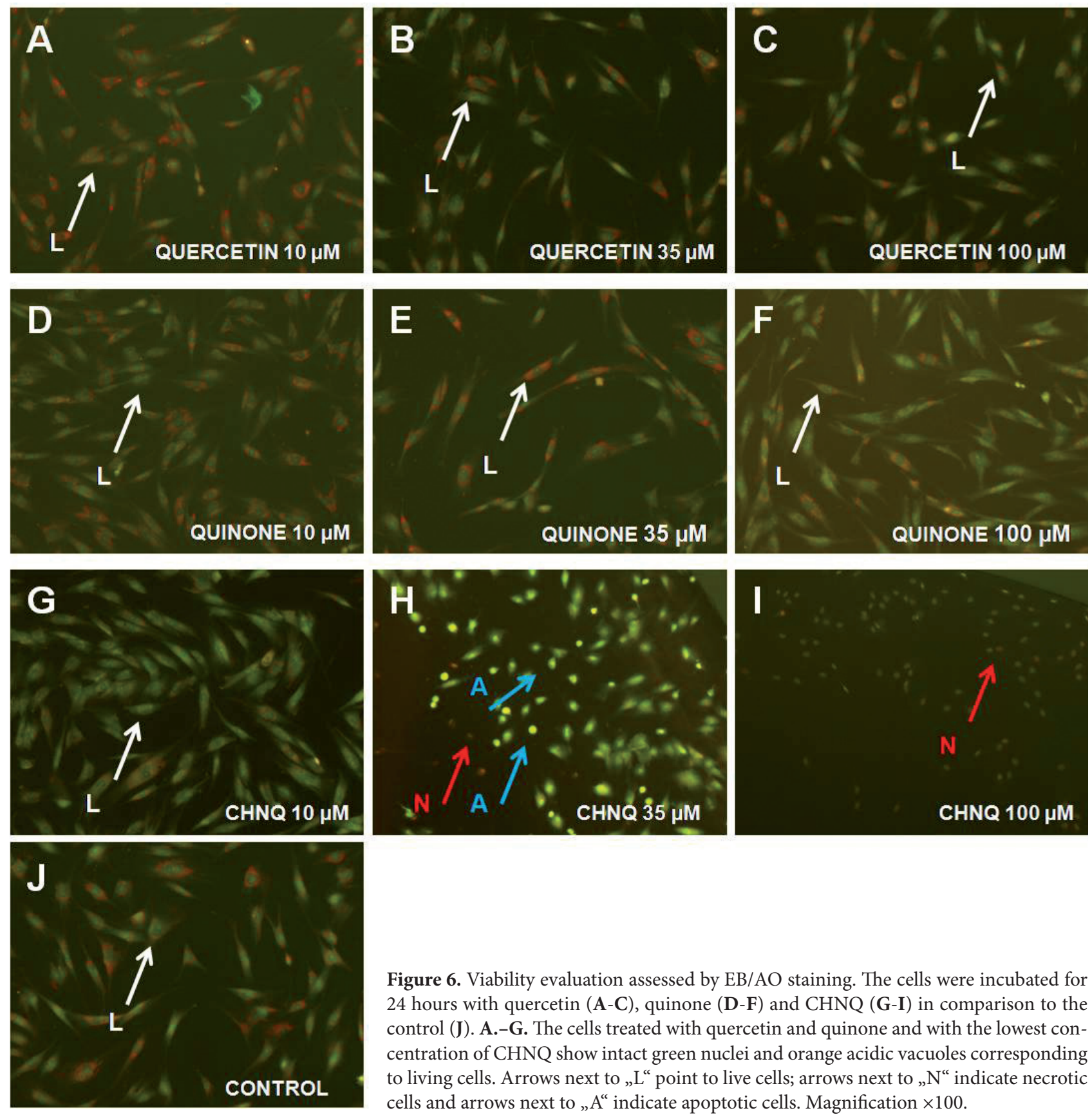

Figure 6. Viability evaluation assessed by $\mathrm{EB} / \mathrm{AO}$ staining. The cells were incubated for 24 hours with quercetin (A-C), quinone (D-F) and CHNQ (G-I) in comparison to the control (J). A.-G. The cells treated with quercetin and quinone and with the lowest concentration of CHNQ show intact green nuclei and orange acidic vacuoles corresponding to living cells. Arrows next to „L“ point to live cells; arrows next to „N“ indicate necrotic cells and arrows next to „A“ indicate apoptotic cells. Magnification $\times 100$. 
redox cycling reaction (O'Brien, 1991). As shown by $\mathrm{H}_{2} \mathrm{DCF}$ oxidation, a profound increase of superoxide secondary metabolites were also seen in CHNQ-treated cells. The lack of DCF fluorescence at the maximum concentration tested might be explained by a loss of barrier ability of the membrane (probably due to massive cell death as well as advanced membrane lipid oxidation) and probe leakage into the medium. Furthermore, unlike the weaker electron-acceptors quinone and quercetin, CHNQ induced cell death predominantly via apoptosis, a phenomenon typical for biologically relevant quinones (Qiu et al. 1998; Gomez-Monterrey et al. 2010; Massaoka et al. 2012). Similarly to pro-apoptotic effects of other quinones (such as jacaranone and thymoquinone (El Mahdy et al. 2005; Massaoka et al. 2012)), the apoptosis induced by CHNQ involved caspase- 8 activation and loss of mitochondrial membrane potential (MMP). Mitochondrial dysfunction, characterized by a loss of MMP and opening of mitochondrial permeability transition pores, is an effect caused by many apoptotic stimuli including ROS (Kuwana et al. 2005; Le Bras et al. 2005). In consequence, mitochondria release various intermembrane space proteins to the cytosol including cytochrome c leading to activation of the caspase cascade, including activation of the key caspase-3. It has been clearly shown that ROS trigger activation of caspases, including caspase-2, -8, -9 and -3, during apoptosis (Prasad et al. 2006; Massaoka et al. 2012). Activation of caspase-8 during CHNQ-induced apoptosis draws attention to the role of deathreceptor-mediated pathway. However, caspase- 8 can also amplify the apoptotic signal through the mitochondrial pathway. Activated caspase- 8 cleaves BH3 domain-only members of the Bcl-2 family, such as proapoptotic Bid, followed by their entry into mitochondria and induction of cytochrome $\mathrm{c}$ release (Yin 2000). In addition, it was confirmed that activation of caspase-8 can occur in death receptor-independent apoptosis (Lin et al. 2004). Caspase-8 was found to work upstream of caspase- 3 activation and initiate the release of cytochrome
A
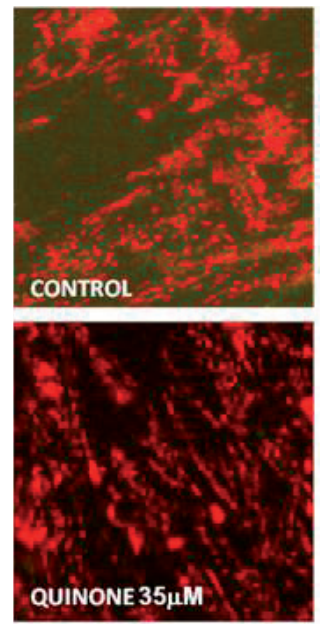

C

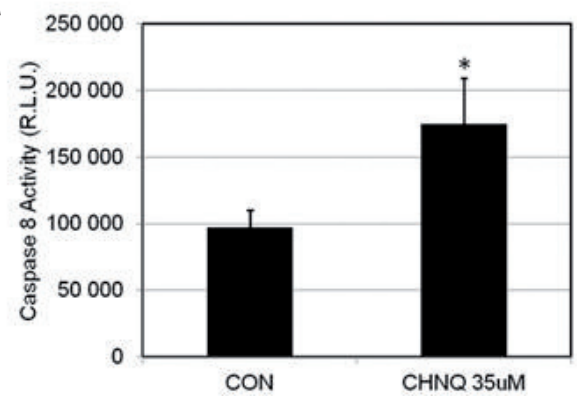

B
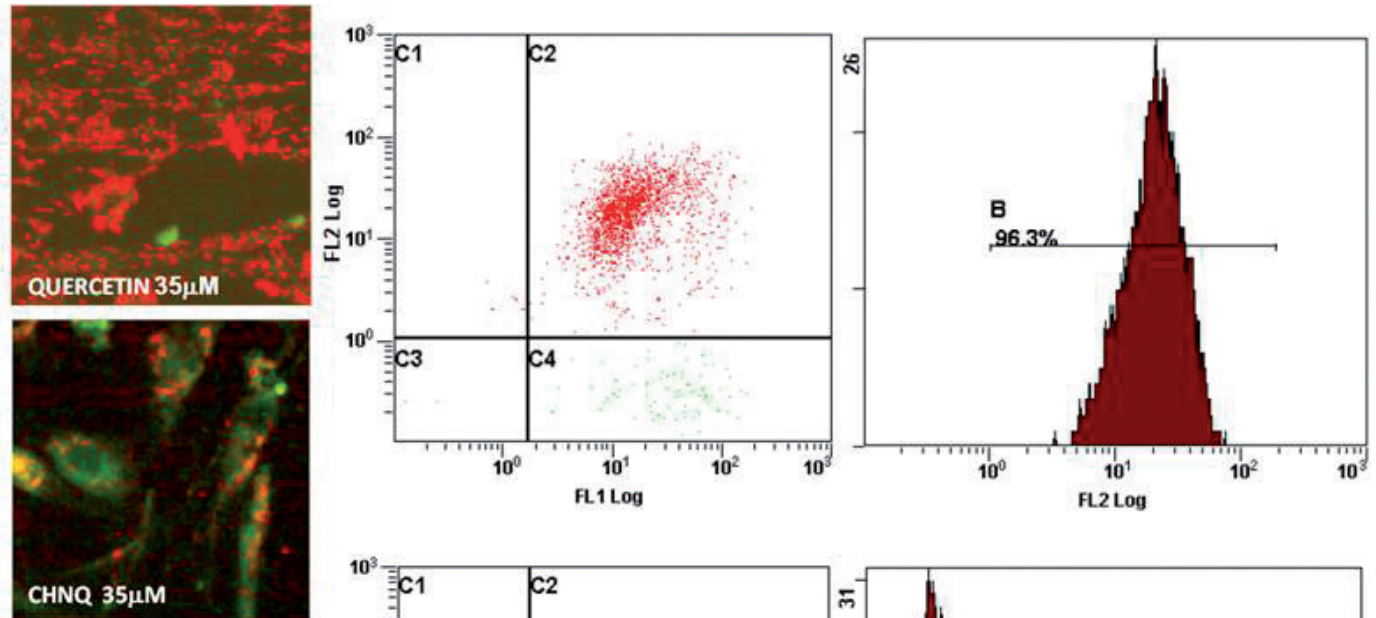

$$
{ }^{100}
$$
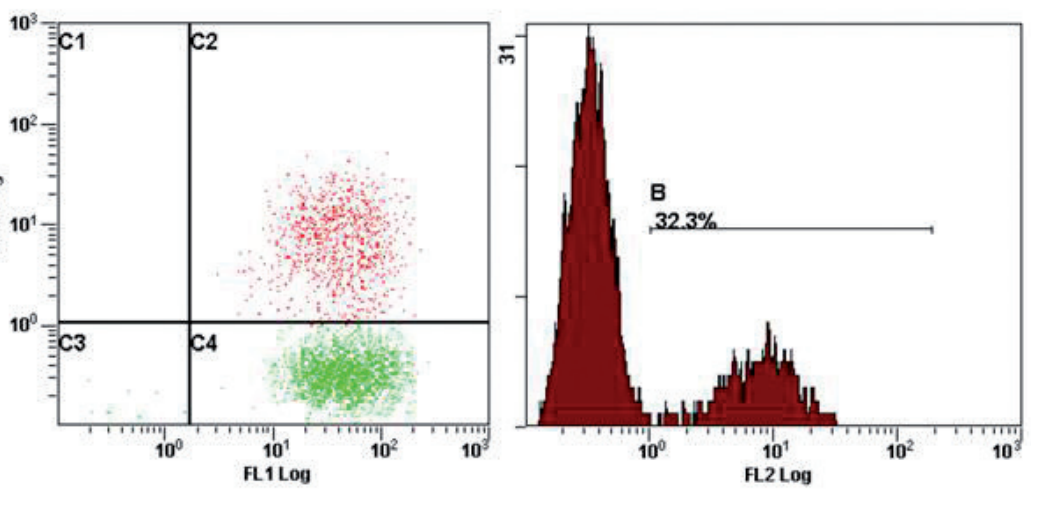

Figure 7. Evaluation of apoptotis in the B-HNF-3 cells exposed to CHNQ. Representative images, dot plots for JC-1 staining and caspase 8 activity evaluation. A. Polarized mitochondria are marked by punctuate orange-red fluorescence staining. On depolarization, the orange-red punctuate staining is replaced by diffuse green fluorescence corresponding to JC-1 monomers. Apoptotic cells, showing mostly green fluorescence, are easily differentiated from healthy cells, which show red fluorescence. B. Representative dot plots of JC-1 stained B-HNF-3 cells. Lower right quadrant shows the cells exhibiting green fluorescing monomers. C. Caspase 8 activation in the B-HNF-3 cells exposed to CHNQ $(35 \mu \mathrm{M})$. R.L.U., relative luminiscence units; ${ }^{\star} p<0.05 v$ s. vehicle DMSO $0.105 \%$. 
$\mathrm{c}$ to the cytosol during thymoquinone-induced apoptosis in HL-60 cells (El- Mahdy et al. 2005).

The carbonyl assay is a frequently used biomarker of protein damage. Carbonyls can arise from protein glycation by sugars, by binding of aldehydes (including many of those formed during lipid peroxidation) to proteins and by the direct oxidation of amino-acid side chains by reactive species to generate such products as glutamate and aminoadipic semialdehydes (Reznick et al. 1992; Calingasan et al. 1999; Chevion et al. 2000; Adams et al. 2001; Requena et al. 2001; Levine 2002; Dalle-Donne et al. 2003). In line with the results of intracellular oxidant production and calculated molecular descriptors, the compound CHNQ caused more profound carbonylation of cytosolic proteins in B-HNF-3 cells than did quinone and quercetin. Both direct oxidation of amino acid side chains and secondary lipid peroxidation products may have contributed to this result.

Results of the MTT reduction assay were in consistency with outcomes of the EB/AO staining assay. The highest cytotoxicity was determined for CHNQ $\left(\mathrm{IC}_{50}=45.6 \pm 2.2\right.$ $\left.\mu \mathrm{M}, \mathrm{IC}_{25}=31.5 \pm 1.2 \mu \mathrm{M}\right)$, while both its precursors tested showed low cytotoxicity $\left(\mathrm{IC}_{50}>100 \mu \mathrm{M}, \mathrm{IC}_{25}=89.3 \pm 24.0\right.$ $\mu \mathrm{M}$ and $\mathrm{IC}_{25}=96.5 \pm 26.9 \mu \mathrm{M}$ for quercetin and quinone, respectively) in B-HNF-3 fibroblasts.

Furthermore, we tested the hypothesis that CHNQ may intracellulary undergo hydrolysis to quercetin and quinone.

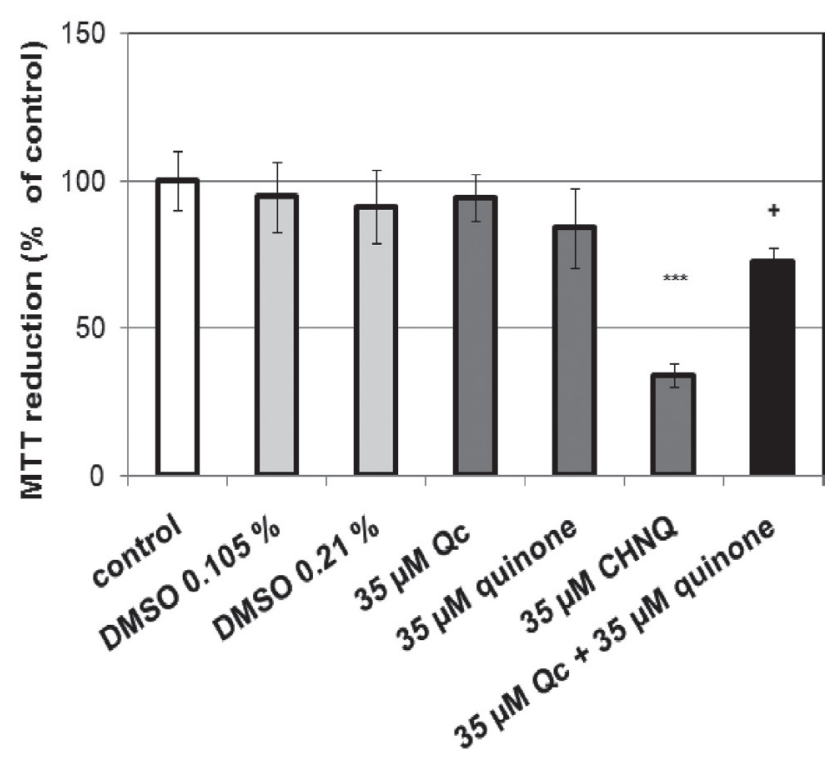

Figure 8. Comparison of the effects of CHNQ and the corresponding equimolar mixture of its precursors quercetin $(\mathrm{Qc})$ and quinone on viability assessed by MTT assay. The B-HNF- 3 cells grown on the 96-well plate were incubated with the three individual compounds at $35 \mu \mathrm{M}$ concentration or with the sum of precursors of CHNQ $(35 \mu \mathrm{M})$ or a vehicle at corresponding concentrations for 24 hours. ${ }^{+} p<0.05 v$. vehicle DMSO $0.21 \%$, ${ }^{* *} p<0.001$ vs. vehicle DMSO $0.11 \%$ ).
Yet CHNQ showed a profoundly higher cytotoxicity than the simple mixture of its precursors, which may be indicative of its intracellular stability in fibroblast cells, at least during 24 hours. In addition, this result suggests that the fused

A

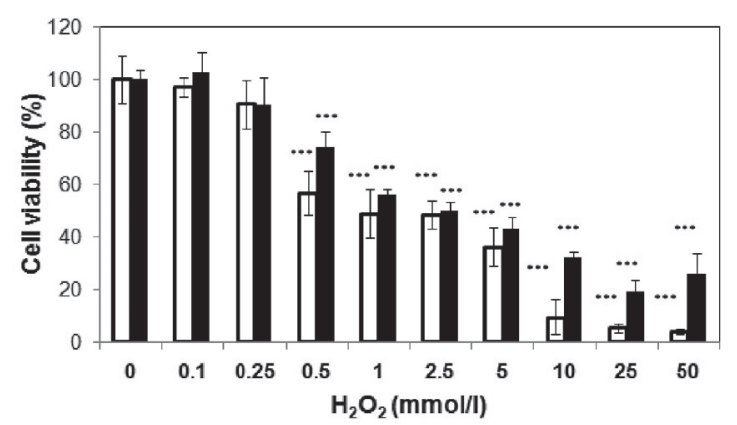

B
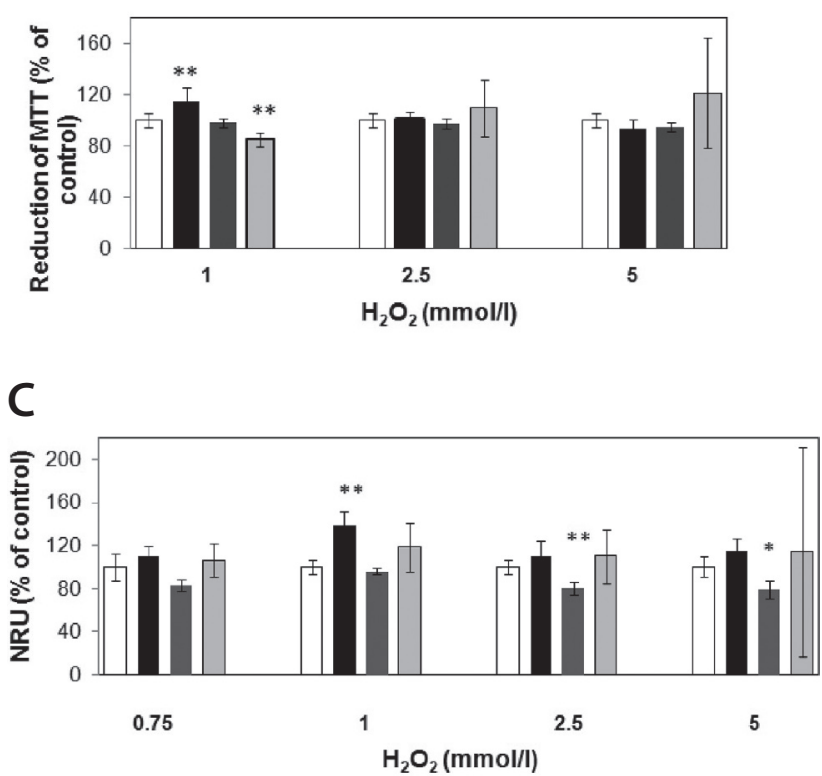

Figure 9. The concentration-dependent injury of activity of mitochondrial dehydrogenases (confirmed by MTT conversion decline) and lysosomal injury (proved by diminishment of neutral red uptake) and protective effect of pre-treatment with CHNQ $(10 \mu \mathrm{M})$. A. The cells grown on the 96 -well plate were incubated with different concentrations of $\mathrm{H}_{2} \mathrm{O}_{2}$ for 1 hour. The viabilities in MTT (the black graphic columns) and NRU assay (the white graphic columns) were determined as percentages of untreated control. ${ }^{* *} p<0.001$. B., C. The B-HNF-3 cells grown on the 96 -well plate were preincubated with the compounds tested at $10 \mu \mathrm{M}$ concentration for 24 hours and then exposed to different concentrations (mM) of $\mathrm{H}_{2} \mathrm{O}_{2}$ for 1 hour. The effects of the compounds tested on viability injury were assessed by MTT (B) and NRU assays $(\mathbf{C}) .{ }^{*} p<0.05$, ${ }^{* *} p<0.01$ vs. $\mathrm{H}_{2} \mathrm{O}_{2}$ control. The white graphic columns indicate the control, the black indicate the compound $\mathrm{CHNQ}$, the dark gray quercetin and the light gray quinone. 
structure of CHNQ can be essential for its unique biological properties.

Hydrogen peroxide caused a significant dose-dependent injury of activity of mitochondrial dehydrogenases as well as lysosomal destabilization. A slightly more profound damage to lysosomes compared to the injury of the activity of dehydrogenases might be explained by a higher vulnerability of lysosomes (as a main iron storage compartment) to $\mathrm{H}_{2} \mathrm{O}_{2}$ toxicity.

In support of our proposition of its hormetic properties, CHNQ (a compound showing enhanced cytotoxicity and intrinsic prooxidant features at higher concentrations) at a low dose paradoxically triggered the protection to B-HNF-3 fibroblasts against oxidative stress-induced injury. Upregulation of defence mechanisms via binding to redox-sensitive transcription factor complexes followed by their activation may provide a plausible explanation of this outcome (Itoh et al. 1997; Itoh et al. 1999; Dinkova-Kostova et al. 2001). Furthermore, the moderate increase of ROS generation in mitochondria can also result in an adaptive response that culminates in increased stress resistance and antioxidant defense (Ristow and Schmeisser 2011). On the other hand, quercetin and quinone rather enhanced the damage to cells. Polyphenol-mediated transition metal redox cycling (enhanced under $\mathrm{H}_{2} \mathrm{O}_{2}$-challenge) or the previously reported interaction with cultured media components might explain this outcome (Lapidot et al. 2002; Satoh et al. 2013).

In conclusion, this study showed that the novel chloronaphthoquinone derivative of the flavonoid quercetin (CHNQ) exerted a more profound cytotoxic and prooxidant effect compared to its synthetic precursors, quercetin and quinone. In paradox, these adverse effects might provide cytoprotection at a low dose range, likely through augmentation of the cellular defence system. Thus, CHNQ might have a merit in search for new prospective agents in prevention and management of ageing and its related pathologies.

Conflict of Interest. The authors declare that there are no conflicts of interest.

Acknowledgements. The work was supported by grants VEGA 2/0031/12, VEGA 2/0067/11, by The Agency of the Ministry of Education of the Slovak Republic for the Structural Funds of EU, OP RandD of ERDF as a part of the Project ITMS 26240220040. This contribution is the result of the project implementation: Centre of Excellence for Glycomics, ITMS 26240120031, supported by the Research and Development Operational Programme funded by the ERDF. The work was also supported by The Agency of the Ministry of Education, Science, Research and Sport of the Slovak Republic for the Structural Funds of EU, OP R\&D of ERDF by realization of the Project ITMS Code 26240220005 and supported by the fund VEGA 1/0076/2013.

\section{References}

Adams S., Green P., Claxton R., Simcox S., Williams M. V., Walsh K., Leeuwenburgh C. (2001): Reactive carbonyl formation by oxidative and non-oxidative pathways. Front. Biosci. 6, 17-24 http://dx.doi.org/10.2741/Adams

Akhtar M. W., Sunico C. R., Nakamura T., Lipton S. A. (2012): Redox regulation of protein function via cysteine S-nitrosylation and its relevance to neurodegenerative diseases. Int. J. Cell Biol. 2012, 463756 http://dx.doi.org/10.1155/2012/463756

Awad H. M., Boersma M. G., Vervoort J., Rietjens I. M. (2000): Peroxidase-catalyzed formation of quercetin quinone methideglutathione adducts. Arch. Biochem. Biophys. 378, 224-233 http://dx.doi.org/10.1006/abbi.2000.1832

Bast A., Haenen G. R. (2002): The toxicity of antioxidants and their metabolites. Environ. Toxicol. Pharmacol. 11, 251-258 http://dx.doi.org/10.1016/S1382-6689(01)00118-1

Bergman E. D., Ginsberg D., Rappo R. (1959): The Michael Reaction in Organic Reactions. (Ed. Blatt A. H.), John Wiley and Sons Inc, New York

Birringer M. (2011): Hormetics: dietary triggers of an adaptive stress response. Pharm Res. 28, 2680-2694 http://dx.doi.org/10.1007/s11095-011-0551-1

Bolton J. L., Turnipseed S. B., Thompson J. A. (1997): Influence of quinone methide reactivity on the alkylation of thiol and amino groups in proteins: studies utilizing amino acid and peptide models. Chem. Biol. Interact. 107, 185-200

http://dx.doi.org/10.1016/S0009-2797(97)00079-3

Calabrese E. J., Baldwin L. (1997): The dose determines the stimulation (and poison): development of a chemical hormesis database. Int. J. Toxicol. 16, 545-559 http://dx.doi.org/10.1080/109158197226874

Calingasan N. Y., Uchida K., Gibson G. E. (1999): Protein-bound acrolein: A novel marker of oxidative stress in Alzheimer's disease. J. Neurochem. 72, 751-756 http://dx.doi.org/10.1046/j.1471-4159.1999.0720751.x

Chevion M., Berenshtein E., Stadtman E. R. (2000): Human studies related to protein oxidation: protein carbonyl content as a marker of damage. Free Radic. Res. 33, 99-108

Chondrogianni N., Kapeta S., Chinou I., Vassilatou K., Papassideri I., Gonos E. S. (2010): Anti-ageing and rejuvenating effects of quercetin. Exp. Gerontol. 45, 763-771 http://dx.doi.org/10.1016/j.exger.2010.07.001

Dalle-Donne I., Rossi R., Giustarini D., Milzani A., Colombo R. (2003): Protein carbonyl groups as biomarkers of oxidative stress. Clin. Chim. Acta 329, 23-38 http://dx.doi.org/10.1016/S0009-8981(03)00003-2

Dinkova-Kostova A. T., Massiah M. A., Bozak R. E., Hicks R. J., Talalay P. (2001): Potency of Michael reaction acceptors as inducers of enzymes that protect against carcinogenesis depends on their reactivity with sulfhydryl groups. Proc. Natl. Acad. Sci. 98, 3404-3409 http://dx.doi.org/10.1073/pnas.051632198

El-Mahdy M.A., Zhu Q., Wang Q.-E., Wani G., Wani A. A. (2005): Thymoquinone induces apoptosis through activation of caspase- 8 and mitochondrial events in p53-null myeloblastic leukemia HL-60 cells. Int. J. Cancer 117, 409-417 
http://dx.doi.org/10.1002/ijc.21205

Gasch A., Werner-Washburne M. (2002): The genomics of yeast responses to environmental stress and starvation. Func. Int. Gen. 2, 181-192 http://dx.doi.org/10.1007/s10142-002-0058-2

Gomez-Monterrey I., Campiglia P., Bertamino A., Aquino C., Sala M., Grieco P., Dicitore A., Porta A. et al. (2010): A novel quinone-based derivative (DTNQ-Pro) induces apoptotic death via modulation of heat shock protein expression in Caco-2 cells. Br. J. Pharmacol. 160, 931-940 http://dx.doi.org/10.1111/j.1476-5381.2010.00718.x

Harman D. (1972): A biologic clock: the mitochondria? J. Am. Geriatr. Soc. 20, 145-147

Itoh K., Chiba T., Takahashi S., Ishii T., Igarashi K., Katoh Y., Oyake T., Hayashi N., Satoh K., Hatayama I., Yamamoto M., Nabeshima Y. (1997): An Nrf2/small Maf heterodimer mediates the induction of phase II detoxifying enzyme genes through antioxidant response elements. Biochem. Biophys. Res. Commun. 236, 313-322 http://dx.doi.org/10.1006/bbrc.1997.6943

Itoh K., Wakabayashi N., Katoh Y., Ishii T., Igarashi K., Engel J. D., Yamamoto M. (1999): Keap1 represses nuclear activation of antioxidant responsive elements by Nrf2 through binding to the amoni-terminal Neh2 domain. Genes Dev. 13, 76-86 http://dx.doi.org/10.1101/gad.13.1.76

Kayembe J. S., Taba, K. M., Ntumba, K., Tshiongo, M. T. C., Kazadi, T. K. (2010): In vitro anti-malarial activity of 20 quinones isolated from four plants used by traditional healers in the Democratic Republic of Congo. J. Med. Plants Res. 4, 991-994

Kobayashi A., Kang M. I., Watai Y., Tong K. I., Shibata T., Uchida K., Yamamoto M. (2006): Oxidative and electrophilic stresses activate Nrf2 through inhibition of ubiquitination activity of Keap1. Mol. Cell Biol. 26, 221-229 http://dx.doi.org/10.1128/MCB.26.1.221-229.2006

Kultz D. (2005): Molecular and evolutionary basis of the cellular stress response. Annu. Rev. Physiol. 67, 225-257 http://dx.doi.org/10.1146/annurev.physiol.67.040403.103635

Kuwana T., Bouchier-Hayes L., Chipuk J. E., Bonzon C., Sullivan B. A., Green D. R., Newmeyer D. D. (2005): BH3 domains of BH3-only proteins differentially regulate Bax-mediated mitochondrial membrane permeabilization both directly and indirectly. Mol. Cell 17, 525-535 http://dx.doi.org/10.1016/j.molcel.2005.02.003

Lapidot T., Walker M. D., Kanner J. (2002): Antioxidant and prooxidant effects of phenolics on pancreatic beta-cells in vitro. J. Agric. Food Chem. 50, 7220-7225 http://dx.doi.org/10.1021/jf020615a

Le Bras M., Clément M. V., Pervaiz S., Brenner C. (2005) Reactive oxygen species and the mitochondrial signaling pathway of cell death. Histol. Histopathol. 20, 205-219

Lee J. M., Johnson J. A. (2004): An important role of Nrf2-ARE pathway in the cellular defense mechanism. J. Biochem. Mol. Biol. 37, 139-143 http://dx.doi.org/10.5483/BMBRep.2004.37.2.139

Levine R. L. (2002): Carbonyl modified proteins in cellular regulation, aging, and disease. Free Radic. Biol. Med. 32, 790-796
http://dx.doi.org/10.1016/S0891-5849(02)00765-7

Li W.W., Heinze J., Haehnel W. (2005): Site-specific binding of quinones to proteins through thiol addition and addition-elimination reactions. J. Am. Chem. Soc. 127, 6140-6141 http://dx.doi.org/10.1021/ja050974x

Lin C. F., Chen C. L., Chang W. T., Jan M. S., Hsu L. J., Wu R. H., Tang M. J., Chang W. C., Lin Y. S. (2004): Sequential caspase-2 and caspase-8 activation upstream of mitochondria during ceramideand etoposide-induced apoptosis. J. Biol. Chem. 279, 40755-40761 http://dx.doi.org/10.1074/jbc.M404726200

Massaoka M. H., Matsuo A. L., Fiqueiredo C. R., Farias C. F., Girola N., Arruda D. C., Scutti J. A., et al. (2012): Jacaranone induces apoptosis in melanoma cells via ROS-mediated downregulation of Akt and p38 MAPK activation and displays antitumor activity in vivo. PLoS One 7, e38698 http://dx.doi.org/10.1371/journal.pone.0038698

Mathers J., Fraser J. A., McMahon M., Saunders R. D., Hayes J. D., McLellan L. I. (2004): Antioxidant and cytoprotective responses to redox stress. Biochem. Soc. Symp. 71, 157-176

Metodiewa D., Jaiswal A. K., Cenas N., Dickancaite E., Segura Aguilar J. (1999): Quercetin may act as a cytotoxic prooxidant after its metabolic activation to semiquinone and quinoidal product. Free Radic. Biol. Med. 26, 107-116 http://dx.doi.org/10.1016/S0891-5849(98)00167-1

Milackova I., Kovacikova L., Veverka M., Gallovic J., Stefek M. (2013): Screening for antiradical efficiency of 21 semi-synthetic derivatives of quercetin in a DPPH assay. Interdiscipl. Toxicol. 6, 13-17

http://dx.doi.org/10.2478/intox-2013-0003

Murota K., Terao J. (2003): Antioxidative flavonoid quercetin: implication of its intestinal absorption and metabolism. Arch. Biochem. Biophys. 417, 12-17 http://dx.doi.org/10.1016/S0003-9861(03)00284-4

O'Brien P. J. (1991): Molecular mechanisns of quinone cytotoxicity. Chem.-Biol. Interactions. 80, 1-41 http://dx.doi.org/10.1016/0009-2797(91)90029-7

Pietsch K., Saul N., Chakrabarti S., Sturzenbaum S. R., Menzel R., Steinberg C. E. (2011): Hormetins, antioxidants and prooxidants: defining quercetin-, caffeic acid- and rosmarinic acid-mediated life extension in C. elegans. Biogerontology 12, 329-347 http://dx.doi.org/10.1007/s10522-011-9334-7

Prasad V., Chandele A., Jagtap J. C., Kumar S., Shastry P. (2006): ROS-triggered caspase 2 activation and feedback amplification loop in $\beta$-carotene-induced apoptosis. Free Radic. Biol. Med. 41, 431-442 http://dx.doi.org/10.1016/j.freeradbiomed.2006.03.009

Przybysz A. J., Chloe K. P., Roberts L. J., Strange K. (2009): Increased age reduces DAF-16 and SKN-1 signaling and the hormetic response of Caenorhabditis elegans to the xenobiotic juglone. Mech. Ageing Dev. 130, 357-369 http://dx.doi.org/10.1016/j.mad.2009.02.004

Qiu X., Schonthal A., Cadenas E. (1998): Anticancer quinones induce $\mathrm{pRb}$-preventable G2/M cell cycle arrest and apoptosis. Free Radic. Biol. Med. 24, 848-854 http://dx.doi.org/10.1016/S0891-5849(97)00368-7

Rackova L., Snirc V., Jung T., Stefek M., Karasu C., Grune T. (2009): Metabolism induced oxidative stress is a mediator of glucose toxicity in HT22 neuronal cells. Free Radic. Res. 24, 1-11 
Renvoize C., Biola A., Pallardy M., Breard J. (1998): Apoptosis: identification of dying cells. Cell. Biol. Toxicol. 14, $111-120$ http://dx.doi.org/10.1023/A:1007429904664

Repiská V., Varga I., Lehocký I., Bőhmer D., Blaško M., Polák Š., Adamkov M., Danišovič L'. (2010): Biological and morphological characterization of human neonatal fibroblast cell culture B-HNF-1. Biologia 65, 919-924 http://dx.doi.org/10.2478/s11756-010-0095-6

Requena J. R., Chao C. C., Levine R. L., Stadtman E. R. (2001): Glutamic and aminoadipic semialdehydes are the main carbonyl products of metal-catalyzed oxidation of proteins. Proc. Natl. Acad. Sci. U.S.A. 98, 69-74 http://dx.doi.org/10.1073/pnas.98.1.69

Reznick A. Z., Cross C. E., Hu M. L., Suzuki Y. J., Khwaja S., Safadi A., Motchnik P. A., Packer L., Halliwell B. (1992): Modification of plasma proteins by cigarette smoke as measured by protein carbonyl formation. Biochem. J. 286, 607-611

Prasad V., Chandele A., Jagtap J. C., Sudheer K. P., Shastry P. (2006): ROS-triggered caspase 2 activation and feedback amplification loop in beta-carotene-induced apoptosis. Free Radic. Biol. Med. 41, 431-442 http://dx.doi.org/10.1016/j.freeradbiomed.2006.03.009

Ribble D., Goldstein N. B., Norris D. A., Shellman Y. G. (2005): A simple technique for quantifying apoptosis in 96-well plates. BMC Biotechnol. 5, 12-19 http://dx.doi.org/10.1186/1472-6750-5-12

Ristow M., Schmeisser S. (2011): Extending life span by increasing oxidative stress. Free Radic. Biol. Med. 51, 327-336 http://dx.doi.org/10.1016/j.freeradbiomed.2011.05.010

Satoh T., McKercher S. R., Lipton S. A. (2013): Nrf2/ARE-mediated antioxidant actions of pro-electrophilic drugs. Free Radic. Biol. Med. 65, 645-657 http://dx.doi.org/10.1016/j.freeradbiomed.2013.07.022

Sedding D. G. (2008): FoxO transcription factors in oxidative stress response and ageing- a new fork on the way to longevity? Biol. Chem. 389, 279-283

http://dx.doi.org/10.1515/BC.2008.033

Shao Y., Molnar L. F., Jung Y., Kussmann J., Ochsenfeld C., Brown S. T., Gilbert A. T. B., Slipchenko L. V., Levchenko S. V., O'Neill D. P., et al. (2006): Advances in methods and algorithms in a modern quantum chemistry program package. Phys. Chem. Chem. Phys. 8, 3172-3191 http://dx.doi.org/10.1039/b517914a

Shibayama-Imazu T., Sonoda I., Sakairi S., Aiuchi T., Ann W., Nakajo S., Itabe H., Nakaya K. (2006): Production of superoxide and dissipation of mitochondrial transmembrane potential by vitamin K2 trigger apoptosis in human ovarian cancer TYK-nu cells. Apoptosis 11, 1535-1543 http://dx.doi.org/10.1007/s10495-006-7979-5

Si H., Liu D. (2014): Dietary anti-aging phytochemicals and mechanisms associated with prolonged survival. J. Nut. Biochem. 25, 581-591 http://dx.doi.org/10.1016/j.jnutbio.2014.02.001

Son T. G., Camandola S., Arumugam T. V., Cutler R. G., Telljohann R. S., Mughal M. R., Moore T. A, Luo W., Yu Q. S., Johnson D. A., Johnson J. A., Greig N. H., Mattson M. P. (2010): Plumbagin, a novel Nrf2/ARE activator, protects against cerebral ischemia. J. Neurochem. 112, 1316-1326 http://dx.doi.org/10.1111/j.1471-4159.2009.06552.x

Son T. G., Camandola S., Mattson M. P. (2008): Hormetic Dietary Phytochemicals. Neuromolecular Med. 10, 236-246 http://dx.doi.org/10.1007/s12017-008-8037-y

Stefek M., Kovacikova L., Milackova I., Veverka M., Svajdlenka E., Veverkova E. (2012): Quercetin derivatives, their pharmaceutical composition and use. Industrial Property Office of the Slovak Republic, Patent Application, PP 5006-2012

Tandon V. K., Kumar S. (2013): Recent development on naphthoquinone derivatives and their therapeutic applications as anticancer agents. Expert. Opin. Ther. Pat. 23, 1087-1108 http://dx.doi.org/10.1517/13543776.2013.798303

Thomson R. H. (1971): Naturally Occuring Quinones. Academic Press, New York

Vargas A. J., Burd R. (2010): Hormesis and synergy: pathways and mechanisms of quercetin in cancer prevention and management. Nutr. Rev. 68, 418-428 http://dx.doi.org/10.1111/j.1753-4887.2010.00301.x

Veverka M., Gallovic J., Svajdlenka E., Veverkova E., Pronayova N., Milackova I., Stefek M. (2013): Novel quercetin derivatives: synthesis and screening for antioxidant activity and aldose reductase inhibition. Chem. Papers 67, 76-83 http://dx.doi.org/10.2478/s11696-012-0240-5

Xu K., Wang P., Wang L., Liu C., Xu S., Cheng Y., Wang Y., Li Q., Lei H. (2014): Quinone derivatives from the genus Rubia and their bioactivities. Chem. Biodivers. 11, 341-363 http://dx.doi.org/10.1002/cbdv.201200173

Yin X. M. (2000): Signal transduction mediated by Bid, a pro-death Bcl-2 family proteins, connects the death receptor and mitochondria apoptosis pathways. Cell Res. 10, 161-167 http://dx.doi.org/10.1038/sj.cr.7290045

Received: February 13, 2014

Final version accepted: August 27, 2014

First published online: November 4, 2014 